\title{
Parchment presence and treatment with vitamins on the emergence of coffee seedlings
}

\author{
Luiz Fernandes Cardoso Campos ${ }^{1}$, Eduardo Pradi Vendruscolo ${ }^{2}$, Lucas Marquezan \\ Nascimento ${ }^{3}$, Camila Meira de Abreu Campos ${ }^{1}$, Larissa Leandro Pires ${ }^{3}$, Alexsander \\ Seleguini ${ }^{4}$
}

\author{
${ }^{1}$ Universidade Estadual de Goiás, Campus de São Luís de Montes Belos, São Luís de Montes Belos, Goiás, Brasil. E-mail: \\ luizfernandescampos@hotmail.com, camilaabreuagro@hotmail.com \\ ${ }^{2}$ Universidade Estadual do Mato Grosso do Sul, Unidade Universitária de Cassilândia, Cassilândia, Mato Grosso do Sul, Brasil. E- \\ mail: agrovendruscolo@gmail.com \\ ${ }^{3}$ Universidade Federal de Goiás, Escola de Agronomia, Goiânia, Goiás, Brasil. E-mail: mznlucas@outlook.com, \\ larissapires.ufg@gmail.com \\ ${ }^{4}$ Universidade Federal do Triângulo Mineiro, Campus Universitário de Iturama, Iturama, Minas Gerais, Brasil. E-mail: \\ aseleguini@gmail.com
}

Received: 02/07/2018; Accepted: 29/03/2019.

\section{ABSTRACT}

The seedling production is a stage of great importance for several crops. The seeds of the coffee tree present germination difficulties due to the physical barrier imposed by the parchment. The objective of this study was to evaluate the effect of parchment presence and pre-sowing treatment with vitamins on the emergence of coffee seedlings. The experimental design was completely randomized, in a $2 \times 4$ factorial design (parchment presence $\mathrm{x}$ types of vitamins), in four replicates with 15 seeds per plot. Vitamins concentration was $100 \mathrm{mg}^{-1}$ of thiamine, 100 $\mathrm{mg} \mathrm{l^{-1 }}$ niacin, $50 \mathrm{mg} \mathrm{l}^{-1}$ thiamine $+50 \mathrm{mg} \mathrm{l}^{-1}$ niacin and a control treatment. The evaluations were performed weekly, with the emerged seedlings being counted until the $76^{\text {th }}$ day after sowing. The emergence percentage was obtained after the $146^{\text {th }}$ day after sowing, counting the number of normal seedlings obtained. The parchment removal increases the speed and the emergence percentage of the coffee seedlings. The treatment with vitamin did not influenced the emergence characteristics of the coffee tree.

Keywords: Coffea arabica L., seed technology, scarification, biostimulant.

\section{Presença de pergaminho e tratamento com vitaminas na emergência de plântulas de cafeeiro}

\section{RESUMO}

A produção de mudas é uma etapa de grande importância para diversas culturas. As sementes do cafeeiro apresentam dificuldades de germinação devido à barreira física imposta pelo pergaminho. Objetivou-se com este estudo avaliar o efeito da presença do pergaminho e do tratamento pré-semeadura com vitaminas sobre a emergência de plântulas de cafeeiro. O delineamento experimental utilizado foi inteiramente casualizado, em esquema fatorial $2 \times 4$ (lote de sementes $\mathrm{x}$ tipos de vitaminas) com quatro repetições, sendo 15 sementes em cada parcela. A concentração de vitaminas foi $100 \mathrm{mg} \mathrm{l}^{-1}$ de tiamina, $100 \mathrm{mg} \mathrm{l}^{-1}$ de niacina, $50 \mathrm{mg} \mathrm{l}^{-1}$ de tiamina $+50 \mathrm{mg}$ $\mathrm{l}^{-1}$ de niacina e tratamento controle. As avaliações do teste de emergência foram realizadas por meio de contagens semanais a partir do $76^{\circ}$ dia após a semeadura. A porcentagem de emergência foi obtida após o $146^{\circ}$ dia póssemeadura, computando-se o número de plântulas normais obtidas. A retirada do pergaminho aumentou a velocidade e a porcentagem de emergência das plântulas de cafeeiro. O tratamento das sementes com soluções vitamínicas não tem influência sobre as características de emergência do cafeeiro.

Palavras-chave: Coffea arabica L., tecnologia de sementes, escarificação, bioestimulante. 
Worldwide, about 9.2 million tons of coffee beans were produced in 2016. Within this total, Brazil accounted for a third part, corresponding for-about 3.02 million tons, which were produced in an area equivalent to 2 million hectare (FAOSTAT, 2018). The Brazilian production of Arabica and Conilon coffee totalized 44.97 million bags of benefited coffee, in the 2017 harvest (Conab, 2017). This result was $12.5 \%$ lower than in 2016 (51.37 million bags), and the reduction of the harvest was influenced by the negative biennial effect of the crop.

The beverage generated by the infusion of roasted and ground coffee in hot water has great acceptance by several societies around the world. It is estimated that about 2 billion people or $33 \%$ of the world's population have a periodic consumption of this drink (Rocha et al., 2013). Thus, in order to serve a larger consumer market, it is necessary to adapt and improve the production system by selection of plants with high productive potential and production uniformity (Rocha et al., 2012), which could come from vigorous seedlings (Guimarães et al., 2010).

Vigorous seedlings have greater potential for establishment after transplanting, culminating in adequate development of root and aerial organs. In this way, it is observed that the process of obtaining seedlings have great importance for several cultures (Silveira et al., 2002; Campanharo et al., 2006) and the development of new techniques, aiming at quality improvement.

Many commercial species interest present germination difficulties due to the barriers imposed by chemical and physical elements (Taiz et al., 2017). In the case of coffee, the seeds have the persistent hard endocarp (parchment) which can significantly decrease the germination and seedlings emergence process (Meireles et al., 2007), if not removed. Manual removal of the parchment, however, is time and labor intensive, burdening the seedlings producer. In order to improve the efficiency of this process, less expensive alternatives are being developed. One of them is the immersion of seeds in sodium hypochlorite (Meireles et al., 2007; Sofiatti et al., 2008) and new compounds that have potential to benefit germination.

Although there is no specific legislation to this group of products (Oliveira and Sousa, 2016), the use of biostimulating products is gaining space in the research and production of plantlets of commercial interest. Among the compounds with a biostimulant action, vitamins have provided significant gains in the development of plantlets for some species (Hendawy and El-Din, 2010; Soltani et al., 2014; Kaya et al., 2015; Vendruscolo et al., 2017). However, these gains are related to development of shoot and root after germination. Their effects on initial traits are still poorly reported, requiring further studies.

Thus, this study aimed objective with this was evaluate the effect of the presence of parchment and pre-sowing treatment with vitamins on coffee emergence traits.

The experiment was conducted in the Horticulture Sector of the Federal University of Goiás (EA/UFG), which is located in Goiânia, Goiás state. The seeds were obtained from coffee fruits, Catuaí Amarelo (IAC 62), harvested at a rural property located in the municipality of Itapuranga, at $15^{\circ} 34$ '29 " S, 50 00' 26" W with average altitude of $635 \mathrm{~m}$. According to Köppen classification, the climate of the region is an Aw type (tropical rainy), characterized by the presence of dry winters and rainy summers (Alvares et al., 2013).

The fruits were harvested at cherry coffee stage, from a single matrix plant, aiming to reduce the germination unequivocation by the greater control of dormancy of the primary type (Campos et al., 2015). Hand stripping was performed and the seeds were soaked in water for 24 hours for mucilage fermentation. After fermentation they were washed in tap water, stored in the shade for seven days in a paper bag until reaching approximately $12 \%$ of seed moisture content.

The experimental was installed in a completely randomized design, in a $2 \times 4$ factorial arrangement (parchment presence $\mathrm{x}$ application of vitamins), with four replicates, with 15 seeds per plot. The treatments were with or without parchment and the vitamin application factor was $100 \mathrm{mg} \mathrm{L}^{-1}$ of thiamine, $100 \mathrm{mg}$ $\mathrm{L}^{-1}$ of niacin, $50 \mathrm{mg} \mathrm{L}^{-1}$ of thiamine $+50 \mathrm{mg} \mathrm{L}^{-1}$ of niacin and a control treatment (distilled water). The parchment was removed manually.

The seeds were soaked for two hours in the respective solutions of each treatment and the control treatment in distilled water. The sowing was carried out in washed sand at depth of $2 \mathrm{~cm}$, arranged plastic perforated trays. The experiment was conducted in a shed containing $50 \%$ polyethylene shingles on the sides and at the upper portion, at $4 \mathrm{~m}$ height, equipped with a micro sprinkler irrigation system, with a 5 min irrigation shift three times a day. The emergence test evaluations were weekly performed after the $76^{\text {th }}$ day after sowing, counting the number of seeds that ruptured the substrate surface. The emergence speed index (ESI) was calculated according to the equation of Maguire (1962):

$$
E S I=\frac{E 1}{T 1}+\frac{E 2}{T 2}+\cdots+\frac{E n}{T n}
$$

On what:

ESI - emergence speed index;

E1; E2; En - number of seedlings emerged in the first, second and last count.

$\mathrm{T} 1 ; \mathrm{T} 2 ; \mathrm{Tn}$ - first, second and last day of evaluation. 
The final percentage of emergence was obtained 146 days after sowing, computing the number of normal seedlings obtained. Data were submitted to analysis of variance by the $\mathrm{F}$ test and the means were compared by the Tukey test with $5 \%$ probability of error.

A significant effect of parchment presence was observed on the emergence of coffee seedlings (Table 1). The absence of parchment in the seeds resulted in an increase of rate of emergence evaluated by the ESI and in the percentage of normal seedlings emerged at 146 days after sowing (Table 1).

Araujo et al. (2016) also found a higher ESI, evaluating the parchment removal in seeds of ten coffee cultivars. The parchment is one of the structures which are present in the coffee seeds that most negatively influences the process of resumption of embryo growth, compromising the percentage and speed of seed germination (Meireles et al., 2007). Besides accelerating the germination and, consequently, reducing the time spent in germination test and in the seedling production phase (Meireles et al., 2007), its removal improves the conditions for the emission of the primary root, without any damage to the embryo structure (Lima et al., 2012).

The use of vitamin did not produce any significant effect on emergence variables, final percentage or speed (Table 1). The result is related to the protective action and biostimulating nature of these vitamins after emergence, not interfering in emergence. As observed by Vendruscolo et al. (2017), the applied niacin via soil favored the development of aerial organs and increases in the levels of foliar chlorophyll. These authors related the action of niacin to the photosynthesizing apparatus of plants. In this case the effect is conditioned to the previous development of the aerial tissues. The appropriate conditions (controlled environment) for germination and early development in the present study may also have contributed to the non-detection of effects related to the exogenous application of thiamine. The use of this vitamin has been emphasized when interacting with stress factors during the development of the embryo. This potential protective effect was verified for the maize culture submitted to saline stress (Kaya et al., 2015).

The presence of parchment has influenced the emergence speed (Figure 1). The emergence of seeds without parchment began on the $76^{\text {th }}$ day after sowing, and at the end of the evaluations presented an emergency rate of $86.33 \%$. Differently, the parchment delayed the emergence of seedlings that began on the $111^{\text {th }}$ day after sowing, the maximum value of emergence reached was $16.00 \%$ at the end of the evaluation period. According to Sofiatti et al. (2009), the parchment removal is an efficient practice in accelerating the emergence of Coffea sp., thus canceling the physical barrier imposed on the seed (Araujo et al., 2016).

These results are also related to the physical barrier imposed by the impermeability of the parchment, which prevents proper hydrolysis of the reserves and hydration of the embryo (Taiz et al., 2017).

This feature is shared with several other species of commercial and native interest. For species of the Anonaceae family, such as Rollinia mucosa (Jacq.) Baill (Campos et al., 2015) and Annona squamosa L. (Vasconcelos et al., 2015), mechanical scarification accompanied by the application of gibberellic acid significantly increases seed germination. Mechanical scarification was also effective for increasing the emergence of Euterpe oleracea (Mart.) (Silva et al., 2015) and Tamarindus indica (Segato et al., 2017).

Table 1 - Emergence speed index (ESI) and seedlings emergence $(\%)$ for coffee seeds with or without parchment, treated with vitamin solutions.

\begin{tabular}{|c|c|c|}
\hline Parchment presence & ESI & Seedlings emergence $(\%)$ \\
\hline With parchment & $0.61 \mathrm{~b}$ & $16.00 \mathrm{~b}$ \\
\hline Without parchment & $1.05 \mathrm{a}$ & $86.33 \mathrm{a}$ \\
\hline MSD & 0.096 & 7.90 \\
\hline \multicolumn{3}{|l|}{ Vitamin application } \\
\hline $100 \mathrm{mg} \mathrm{L}^{-1}$ thiamine & $0.58 \mathrm{a}$ & $50.83 \mathrm{a}$ \\
\hline $100 \mathrm{mg} \mathrm{L}^{-1}$ niacin & $0.51 \mathrm{a}$ & $52.50 \mathrm{a}$ \\
\hline $50 \mathrm{mg} \mathrm{L}^{-1}$ thiamine $+50 \mathrm{mg} \mathrm{L}^{-1}$ niacin & $0.56 \mathrm{a}$ & $49.16 \mathrm{a}$ \\
\hline Control & $0.57 \mathrm{a}$ & $51.67 \mathrm{a}$ \\
\hline MSD & 0.189 & 15.54 \\
\hline $\mathrm{CV} \%$ & 26.84 & 23.96 \\
\hline
\end{tabular}

Means followed by the same letter in the column do not differ from each other by the Tukey test at $5 \%$ of probability. 


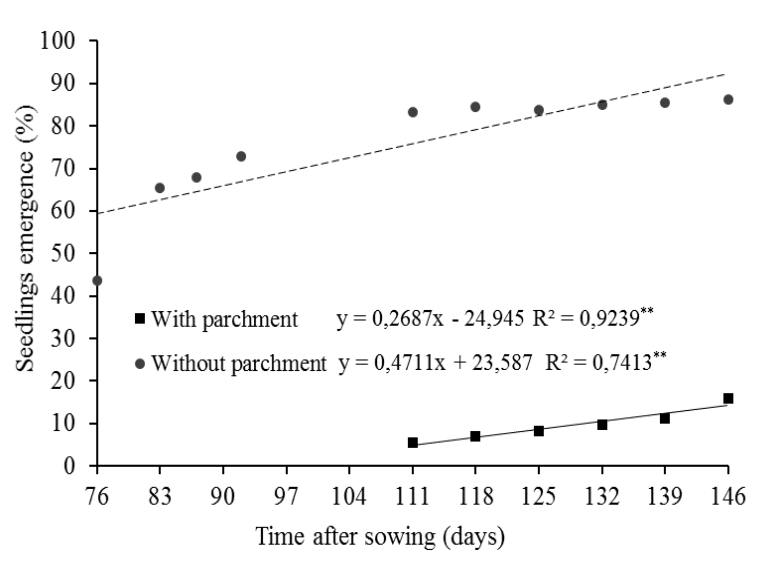

Figure 1 - Emergency rate of coffee seedlings during the evaluation period. ${ }^{* *}$ significant $(\mathrm{p}<0,01)$.

The parchment removal increases the speed and the emergence percentage of the coffee seedlings. The seed treatment with vitamin did not influence emergence of the coffee seedlings.

\section{Bibliographic References}

Alvares, C.A., Stape, J.L., Sentelhas, P.C., Gonçalves, J.L.M., Sparovek, G., 2013. Köppen's climate classification map for Brazil. Meteorologische Zeitschrift, 22, 711-728.

Araujo, A.V., Araujo, E.F., Abud, H.F., Araujo, I.C.V.F., 2016. Utilização da técnica SECAFÉ em sementes de diferentes cultivares. Coffee Science, 11, 386-394.

Campanharo, M., Rodrigues, J.J.V., Junior, M.D.A.L., Espindula, M.C., Costa, J.V.T., 2006. Características físicas de diferentes substratos para produção de mudas de tomateiro. Revista Caatinga, 19, 140-145.

Campos, L.F.C., Abreu, C.M., Guimarães, R.N., Seleguini, A., 2015. Scarification and gibberellic acid on emergence and seedling growth of Biribá. Ciência Rural, 45, 1748-1754.

Conab, 2017. Acompanhamento da safra brasileira: café. Conab, 4, 84 p.

FAOSTAT, 2018. Agricultural Statistics Database. 2016. http://faostat3.fao.org/download/Q/QC/E (acessado 20 de fevereiro de 2018).

Guimarães, R.J., Mendes, A.N.G., Baliza, D.P. (Ed.), 2010. Semiologia do cafeeiro: sintomas de desordens nutricionais, fitossanitárias e fisiológicas. Lavras, UFLA.

Hendawy, S.F., El-Din, A.A.E., 2010. Growth and yield of Foeniculum vulgar var. Azoricum as influensed by some vitamins and amino acids. Ozean Journal Applied Science, 3, 113-123.

Kaya, C., Ashraf, M., Sonmez, O., Tuna, A.L., Polat, T., Aydemir, S., 2015. Exogenous application of thiamin promotes growth and antioxidative defense system at initial phases of development in salt-stressed plants of two maize cultivars differing in salinity tolerance. Acta Physiologiae Plantarum, 37, 1741.
Lima, J.S., Araujo, E.F., Araujo, R.F., Santos, L.A.D., Santos, D.C.F.D., Rena, F.C., 2012. Uso da reidratação e do hipoclorito de sódio para acelerar a emergência de plântulas de cafeeiro. Journal of Seed Science, 34, 1-7.

Meireles, R.C., Araujo, E.F., Reis, M.S., Sediyama, C.S., Sakiyama, N.S., Reis, L.S.D., 2007. Secafé: metodologia para acelerar a germinação das sementes de café. Revista Brasileira de Sementes, 29, 90-96.

Oliveira, N.T., Sousa, S.M., 2016. Avaliação de plântulas de milho sob efeito de bioestimulantes em solução nutritiva. Sete Lagoas, Embrapa Milho e Sorgo.

Rocha, R.B., Ramalho, A.R., Teixeira, A.L., Vieira, D.D.S., 2012. Monitoramento da variabilidade genética de banco ativo de germoplasma de café Conilon (Coffea canephora). Campo Grande, Embrapa Rondônia.

Rocha, R.B., Santos, D.V., Ramalho, A.R., Teixeira, A.L., 2013. Caracterização e uso da variabilidade genética de banco ativo de germoplasma de Coffea canephora Pierre ex Froehner. Coffee Science, 8, 478-485.

Segato, S.V., Munduruca, L.C., Souza, V.M.S., 2017. Sanidade de sementes e emergência de plântulas de sementes de Tamarindus indica submetida a diferentes tratamentos prégerminativos. Nucleus, 14, 237-246.

Silva, L.L., Lima-Primo, H.E., Smiderle, O.J., Chagas, E.A., Souza, A.G., 2015. Escarificação de sementes para desenvolvimento em plântulas de açaizeiro. Revista Agro@mbiente, 9, 72-78.

Silveira, E.B., Rodrigues, V.J.L.B., Gomes, A.M.A., Mariano, R.L.R., Mesquita, J.C.P., 2002. Pó de coco como substrato para produção de mudas de tomateiro. Horticultura Brasileira, 20, 211-216.

Sofiatti, V., Araújo, E.F., Araújo, R.F., Cargnin, A., Reis, M.S., Silva, L.V.B.D., 2009. Uso de hipoclorito de sódio para acelerar a emergência das plântulas e o desenvolvimento das mudas de cafeeiro. Bragantia, 68, 233-240.

Sofiatti, V., Araújo, E.F., Araújo, R.F., Reis, M.S., Silva, L.V.B.D., Cargnin, A., 2008. Uso do hipoclorito de sódio para degradação do endocarpo de sementes de cafeeiro com diferentes graus de umidade. Revista Brasileira de Sementes, $30,150-160$.

Soltani, Y., Saffari, V.R., Moud, A.A.M., 2014. Response of growth, flowering and some biochemical constituents of Calendula officinalis L. to foliar application of salicylic acid, ascorbic acid and thiamine. Ethno-Pharmaceutical Products, 1, $37-44$.

Taiz, L., Zeiger, E., Moller, I.M., Murphy, A., 2017. Fisiologia e desenvolvimento vegetal, sexta ed. Porto Alegre, Artmed.

Vasconcelos, L.H.C., Vendruscolo, E.P., Vasconcelos, R.F., Santos, M.M., Seleguini, A., 2015. Utilização de métodos físicos e de fitorreguladores para superação de dormência em sementes de pinha. Revista de Agricultura Neotropical, 2, 20 24.

Vendruscolo, E.P., Martins, A.P.B., Seleguini, A., 2017. Doses e parcelamento de niacina no desenvolvimento inicial de meloeiro Cantaloupe. Revista Agro@ mbiente, 11, 209-214. 